Article

\title{
Study on the Value Model of Urban Green Infrastructure Development-A Case Study of the Central District of Taichung City
}

\author{
Kuo-Wei Hsu and Jen-Chih Chao *(D)
}

check for updates

Citation: Hsu, K.-W.; Chao, J.-C. Study on the Value Model of Urban Green Infrastructure

Development-A Case Study of the Central District of Taichung City. Sustainability 2021, 13, 7402. https:// doi.org/10.3390/su13137402

Academic Editors: Karina Pallagst, Rosemarie Stangl, Ulrike Pitha,

Daniela Haluza and

Ingrid Kaltenegger

Received: 1 June 2021

Accepted: 29 June 2021

Published: 1 July 2021

Publisher's Note: MDPI stays neutral with regard to jurisdictional claims in published maps and institutional affiliations.

Copyright: (c) 2021 by the authors. Licensee MDPI, Basel, Switzerland. This article is an open access article distributed under the terms and conditions of the Creative Commons Attribution (CC BY) license (https:// creativecommons.org/licenses/by/ $4.0 /)$.
Department of Landscape and Urban Design, Chaoyang University of Technology, Taichung City 413, Taiwan; kwhsu@cyut.edu.tw

* Correspondence: jenchihchao@gmail.com; Tel.: +886-4-2332-3000\#7668

Abstract: Urban green infrastructure has become an important concept for sustainable urban development. Regarding the joining up of green spaces into green networks, it can have major positive impacts on the environment, societies and economies, and ecology. This study proposes a value model for investing in urban green infrastructure, with impact factors including land use value, energy conservation value, carbon reduction, and disaster prevention value. It establishes that through the interaction between all four of these factors, urban green infrastructure investment increases net operating income. Additionally, as disaster prevention value increases, urban disaster risk declines, and this has an important positive effect on overall value. Our modeling also indicates that in the face of climatic extremes, the construction of urban green infrastructure is increasingly important, particularly in terms of energy value and disaster prevention value. Specific incentives and catalysts for promoting investment in urban green infrastructure are proposed.

Keywords: energy saving; carbon reduction; urban green infrastructure; urban disaster prevention; value at risk

\section{Introduction}

Amid increasingly extreme weather conditions and heavy rainfall, flooding has caused financial and other losses to the old and complex urban environment. This has led to a new urban agenda, in which the promotion of environmental sustainability is expected to facilitate transformational change, provided that key linkages are made among the environment, urban planning, and policy governance [1].

The concept of green infrastructure emphasizes the connections among landscape ecology, urban and community living space use, and the implementation of sustainable urban land use planning [2,3]. This is receiving increasing attention, as evidenced by the latest policies and guidance on green infrastructure, referenced by cities and countries around the world (e.g., the UK Green Infrastructure Planning Practice Guide) [4]. As Matthews et al. and Gill et al. have noted, green infrastructure is widely expected to play an important role in adapting societies to some of the anticipated impacts of climate change [5,6]. For example, the creators of the Sustainable Neighborhood Retrofit Action Plan (SNAP) found that by involving older community residents in environmental urbanrenewal actions, gas and electricity consumption were reduced, saving residents and businesses money [7].

In recent years, urban green infrastructure planning has emerged as a distinctive field of endeavor, aimed at creating and managing green spatial networks in urban environments through the application of particular policy themes, planning processes, and methodologies [8-11]. Conceptually, urban green infrastructure connects to the adjacent green infrastructure at the landscape scale, while remaining chiefly focused on creating and managing multifunctional green space networks within the urban environment [12]. Norton et al. reported that the scientific literature supports a relationship between urban green 
infrastructure and temperature mitigation, and gave particular attention to the cooling benefits of four types of urban green infrastructure: green open spaces (primarily parks), vertical greening systems (green walls and facades), shade trees, and green roofs [13]. Creating an urban green infrastructure network that links green spaces at multiple scales requires planners to address groundwater, surface-water, and air-flow systems [14]. Thus, the definitions or typologies of and rationales for urban green infrastructure typology have typically included a broad range of features, e.g., rivers, parks, forests, green routes, which are both natural and designed [8-10]. ECOTEC Research and Consulting (Birmingham, UK) observed that the economic benefits of green infrastructure investments in both the public and private sectors include direct economic generation, indirect economic output, cost reduction, and risk management, alongside quantifiable and non-quantifiable economic benefits [15]. This implies that green infrastructure has a wide range of impacts; therefore, it has considerable potential for mitigating the negative environmental, social, economic, and ecological impacts of climate change. As such, a quantitative value model that can help stakeholders better understand the value of green infrastructure, and provide incentives and catalysts for participation in it, would appear overdue.

Urban green infrastructure transforms the urban environment through green engineering and technology, as well as through green network connection techniques for improving energy efficiency, reducing energy use, lowering carbon emissions from urban buildings and transportation, and enhancing urban disaster preparedness. Thus, the planning of urban green infrastructure has environmental [16,17], social [18,19], economic [20,21], and ecological impacts, in addition to its direct ones $[13,22]$. We decided to conduct the present study at a regional scale, as most prior researchers have discussed urban green infrastructure's economic benefits or value through case studies of individual projects.

\section{Literature Review}

This study's examination of the prior literature on the benefits generated by urban green infrastructure can be divided into three types. These are land use value, energy conservation value, and disaster prevention value. Scholars agree to quantify these benefits in terms of effective increase of economic values as illustrated in the paragraphs below:

\subsection{Land Use Value}

The purpose of sustainable urban development is to re-plan land use functions, promote land use efficiency, and improve townscapes and the health of urban ecosystems. Urban renewal helps to improve environmental quality, establish comprehensive openspace systems and new public spaces, and regulate and mitigate the impact of disasters This is generally done via urban green infrastructure, in the form of greening, green belts and green coverage. The Council of Tree and Landscape Appraisers (CTLA) has indicated that trees increase the value of properties by $15 \%-25 \%$, depending on their size, condition, location, and species class. Other research has tended to confirm this [23,24]. For example, real estate near Mesnes Park in Newton-Le-Willows, Merseyside was found to be $19 \%$ more expensive than comparable real estate in the area [25]. Meanwhile, the systematic addition of trees to urban streets has been linked to a $7 \%$ average rise in real estate prices in Boston Square Sensory Park, Hunstanton [26]. In addition, proximity to, or views of, natural broad-leaf woodland enhances property values. Garrod and Willis estimated that an area around the Forest of Dean in Gloucestershire, with around 20\% woodland coverage, will have house prices that are higher by an average of $7.1 \%$, than a similar area with no woodlands. Furthermore, they found that people were willing to pay $£ 269$ per household per year for a view of forested areas from their houses [27,28]. The average premium that is paid for real estate within a park in Queen Square, Bristol is 16\% [26]. CABE Space (Commission for Architecture and the Built Environment) suggested that the view within an affluent neighborhood, Holland Park, London, raised house prices by $8 \%$, while proximity to the park increased them by $6 \%$ [25]. 
Urban green infrastructure has brought new vitality and hope to places in which it has been implemented. Through the complete re-planning of districts, the amount of available public and open space can both be increased, thus improving such districts' overall environmental quality. These changes in the townscape, in turn, attract more people and businesses, and this can have a snowball effect on the willingness to invest in the area. Cabe Space, for instance, noted that for retailers, a high-quality, carefully planned town center in London can increase business transactions up to $40 \%$, a phenomenon that is likely to lead to significant increases in private sector investment [25]. Additionally, the enhanced image of greener areas attract more tourists, further boosting retail and leisure spending, employment and rental opportunities, and property values, according to a study in Jubilee Park, Canary Wharf, London $[25,26]$. As towns and cities increasingly compete against one another to attract investment, the presence of quality parks, squares, gardens, and other public spaces becomes an important business and marketing tool. Firms are attracted to locations that offer well-designed and well-managed public spaces, which in turn attract customers, staff, and services [29]. In the downtown of Denver, Berlin, Boston, and New York retail districts specifically, a pleasant and well-maintained environment has been found to increase visitor numbers and foot traffic, while increasing the prices that people are willing to pay for goods and services [26]. In short, the greening of urban public environments can have a major impact on the economic life of city centers, and should therefore be considered as a key component of any successful regeneration strategy.

\subsection{Energy Saving Value}

In the context of the sustainable urban development, reducing energy use and carbon emissions are closely related to urban planning decisions. Trees and other plants provide natural thermoregulation, reduce heat evaporation and emissions of artificial heat, limit the production or storage of greenhouse gases, and reduce urban temperatures in the summer [30-32]. Green buildings reduce energy use, lessen the impact of monsoon winds, retain heat in winter, and generally reduce the impact of temperature fluctuations caused by climate change. Su, for example, showed that in Tamshui River, Taipei City during the daytime in summer, temperatures at a shaded waterfront location were $0.2^{\circ} \mathrm{C}-0.7^{\circ} \mathrm{C}$ lower than elsewhere in the same district [33]. The use of dense green trees and permeable pavements can improve the heat storage capacity of streets districts. Similarly, in the surroundings of parks, every $10 \%$ increase in green coverage has been found to reduce prevailing temperatures by $0.17^{\circ} \mathrm{C}-0.22{ }^{\circ} \mathrm{C}$ on summer nights [34]. A $10 \%$ increase in the area covered by green infrastructure in areas of Manchester, that have little or no green coverage, could lead to cooling of up to $2.5^{\circ} \mathrm{C}$ under a high emissions scenario [6]. Parks that are at least three hectares have been shown to be cooler than the surrounding city; however, temperatures in smaller parks are more variable, and the amount of pavement within the parks may also contribute markedly to such variation [35]. The cooling effects of city greens are remarkable, not only on the vegetated areas but also the surrounding built environments [36].

In the process of urban planning, with new pedestrian environments, green spaces and public facilities increase the green coverage of the city to reduce carbon emissions and increase rents, business turnover, and tax revenue [37-39]. The Department of Energy and Climate Change, British government found that the quality of urban environments encouraged people to connect with one another [40].

\subsection{Disaster Prevention Value}

Arguably, the most important goal of sustainable urban development is urban disaster preparedness. In the face of extreme weather challenges, it is important to add open space and public facilities, reduce surface runoff, and improve storm drains. Urban green infrastructure reduces the risk of urban disaster by reducing the impact of extreme weather on cities [41-43]. Urban renewal can incentivize reductions to surface runoff and are likely to be instrumental in mitigating the intensity of disasters, particularly if they are designed 
to complement the construction of green infrastructure [44,45]. Urban green infrastructure can intercept and store water; thus, it reduces both the amount of water loss and reduces stormwater runoff; increases absorption and infiltration rates; reduces the negative impacts of storm water flooding of urban areas; sewage and wastewater treatment networks that reduce flood damage holistically. Natural Economy Northwest (NENW) showed that green infrastructure can also mitigate the effects of pollution, and improve public health, civic pride, and educational opportunities [46]. According to the UK's National Climate and Energy Strategy, green infrastructure can contribute to mitigating and adapting to climate change [40]. Specifically, it can help reduce heat wave and flooding in urban areas by the cooling effect of individual trees, and reduce the rate at which water flows into the ground through infiltration and interception. Furthermore, the implementation of sustainable urban drainage systems in the right locations can play a crucial role in preventing flooding. Therefore, as cities are faced with the impact of climate extremes, they should emphasize the construction of green buildings, the planning of open green spaces and green infrastructure facilities, the improvement of buildings' anti-seismic and drainage systems, enhancement of urban permeability, and the adjustment of urban functions to adapt to the impacts of climate change. Lin pointed out that a higher water retention capacity of a site is associated with a better ability of the site to retain rainwater reduce surface-channel flows during heavy rainfall [47]. In the Brussels area, extensive greening of just $10 \%$ of buildings was found to reduce runoff by $2.7 \%$ overall, and by $54 \%$ for the buildings in question [48].

A cost-benefit analysis of sustainable urban drainage systems in Scotland noted that, if well-designed and maintained, such a system is more cost effective than a conventional one because of its lower construction and maintenance costs [49]. An evaluation of the quality of runoff from large green roofs on multi-story buildings at York University in the City of Toronto, found that it had fewer chemical components than that from conventional roofs [50]. According to Gill et al., adding green space in Manchester will reduce runoff by $4.9 \%$, increasing tree cover will reduce runoff by $5.7 \%$, and green roofs will reduce runoff by between $11.8 \%$ and $14.1 \%$ [6].

Trees with extensive canopies also reduce soil erosion in three ways: by reducing the impact of rainfall on poor surfaces, improving soil strength and stability through the accumulation of organic matter, and binding soil to trees' root systems [51]. Any flood-prone community can use geo-locational information to model how green infrastructure may mitigate flood damage, compare such mitigating effects against the particular infrastructure's cost, and target investment in cost-effective, non-structural flood mitigation policies [52]. Lin et al.'s analysis established that the greener cover is associated with greater water retention, and that this relationship had high positive correlation [53].

\section{Methods}

Research on urban green infrastructure development, as a relatively new sub-field of urban sustainable development, has thus far focused external the economic value when calculating the infrastructures of land development. However, the latest research is examining its other value types and benefits, and is not limited to its mitigation of urban disasters [54]. The existing literature concurs that the value added by urban green infrastructure includes land use value $[26,28,46]$, energy saving value $[6,33,36]$, and disaster prevention value $[50,52,53]$. Meanwhile, academic work on urban land development has traditionally focused on the concepts of economic value [55] and value at risk [56], and when such research accounts for urban green infrastructure, it tends to do so via value modeling. Such modeling has tended to emphasize the value of urban green infrastructure to urban development as part of the process of promoting sustainable urban development, as well as responding to extreme climatic environments and/or events. Specifically, such studies have concluded that the impact of urban disaster prevention value at risk will enhance the promotion of urban green infrastructure, and help to create sustainable urban environments. 


\subsection{Case Study Area}

Located in the Central District of Taichung, the Liuchuan River is a regionally important means of drainage, flowing through densely populated and highly urbanized areas. Due to the long-term impact of sewage that is discharged by communities along its course, the water quality of the river has deteriorated. In addition, due to the rigidity of the river's embankment, interaction between residents and this urban 'blue belt' is severely restricted. A high priority for Central District of Taichung is to improve the water quality of the Liuchuan and its three-sided waterway environment, as part of a wider set of goals, including flood prevention, adequate drainage, and enhancing Taichung's local culture, and quality of life.

Apart from the direct discharge of sewage from both banks, the main reason for the Liuchaun's poor water quality can be found upstream, in the form of domestic sewage. The first priority of the remediation project is to block pollution at the source by intercepting the domestic sewage on both banks of the river, and diverting it to a new underground gravel contact aeration water purification system. The resulting treated sewage will be released as a low impact development demonstration water source section. At the same time, these measures are expected to strengthen the flood control capacity of the river's channel, establish a flood early-warning mechanism, improve the safety of people's recreation on and along the river, improve the appearance and amenity value of the overall environment, and restore the river as a wildlife habitat. In combination with the rich cultural history of the river's urban surroundings, the project will also mean that the day and night times will acquire different styles, necessitating that the area's cultural and commercial spaces will need to be 'flipped', as shown in Figures 1 and 2.

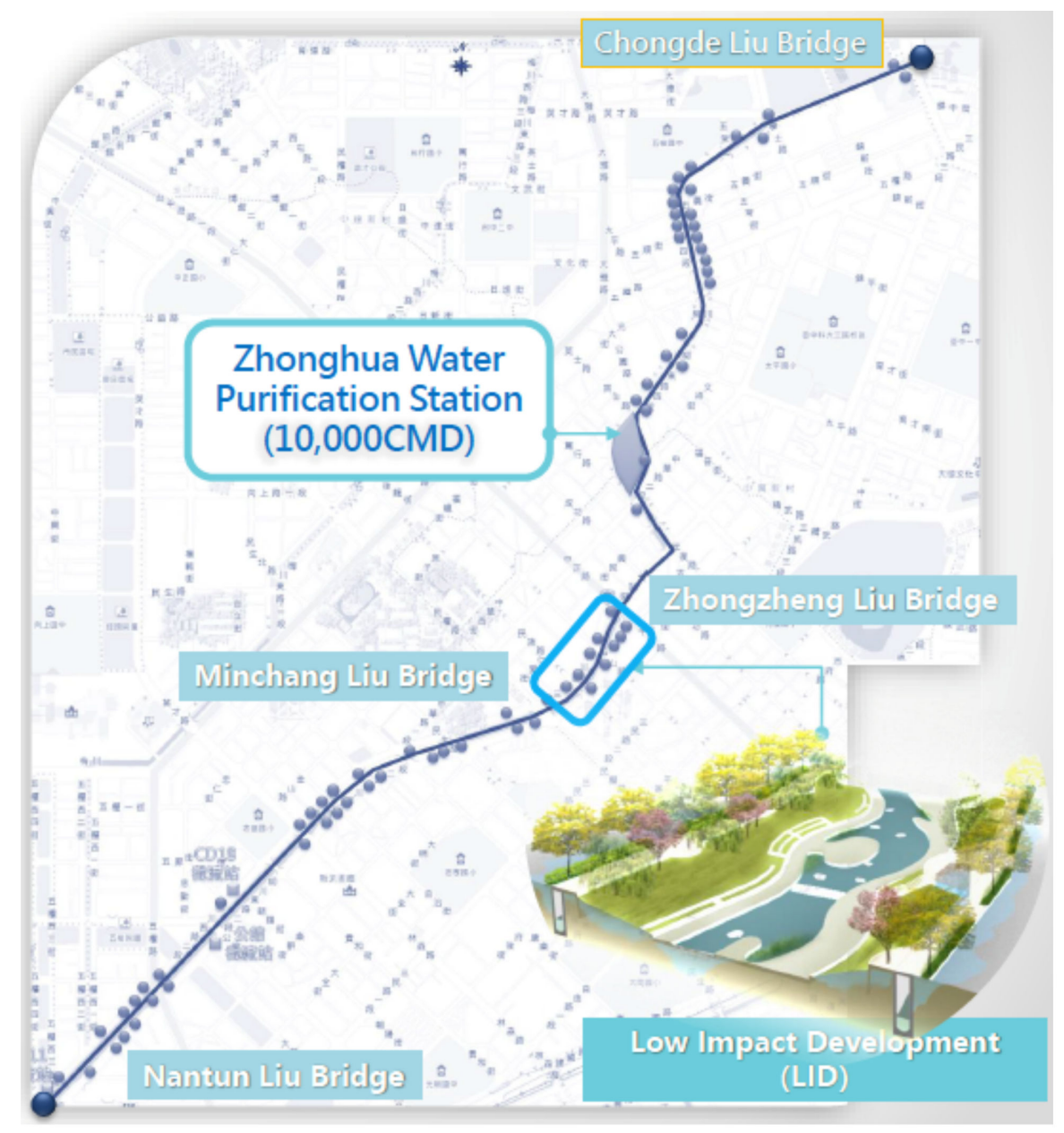

Figure 1. Map of the Liuchuan River Basin in the Central District of Taichung City [57]. 


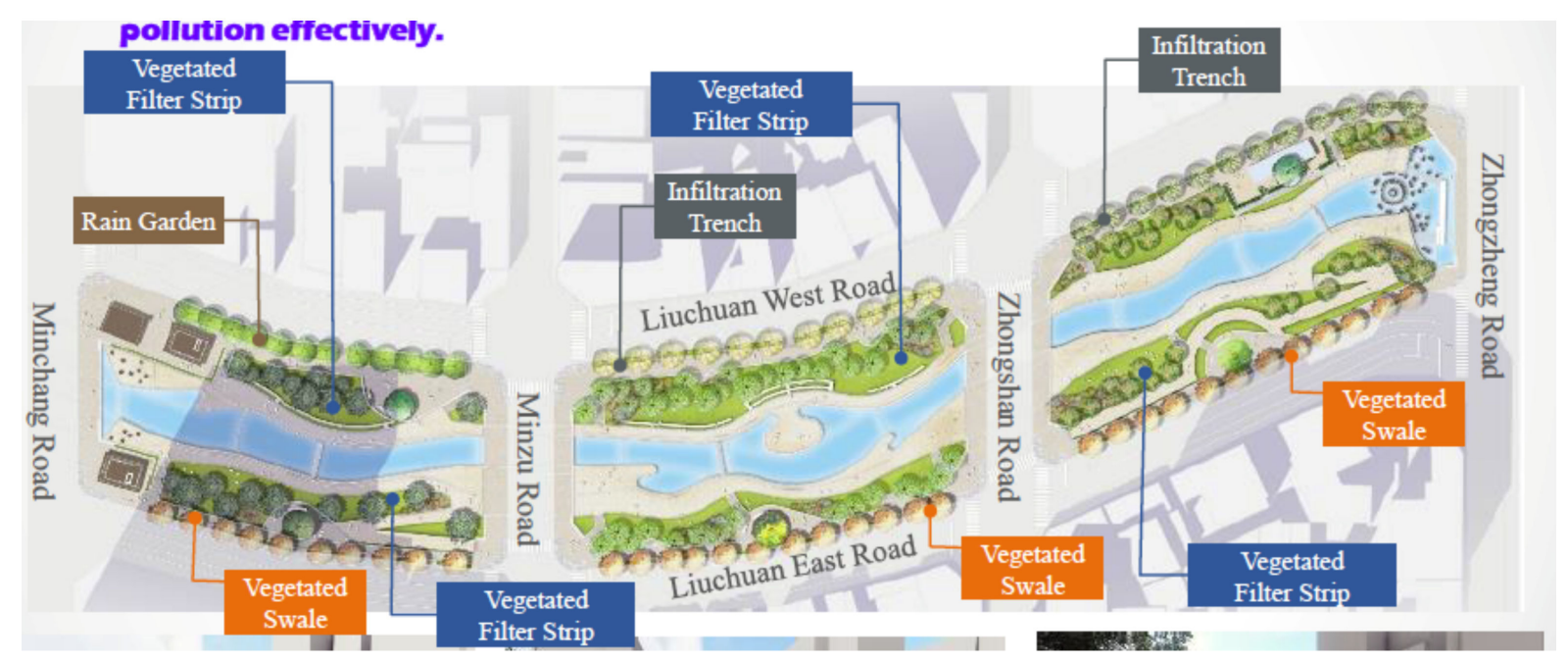

Figure 2. Scope of study [57].

\subsection{Model}

In the process of promoting urban development, it is important to coordinate the planning and design of green buildings, open spaces, and eco-city principles; achieve sustainable urban development, re-plan land use, and improve land use efficiency; and use green infrastructure as the cornerstone of urban planning to create a comfortable and friendly urban environment, re-motivate local development, and enhance the value of local land use.

First, our modeling of urban land development value, net operating income and risk indicates that such income is affected by risk factors, including investment cost, execution period, financial efficiency, building design, energy conservation, and disaster prevention intensity [58]. The risk expectation is used as a quantitative indicator of the financial risk of premium recovery, and the external benefits are financially internalized to present the full value.

As shown in Equation (1) (urban land-development value model [58]), when VaR (Value at Risk) decreases, net operating income increases, thus increasing value; conversely, higher VaR is associated with a falling income and lower value.

$$
\mathrm{V}=\frac{\mathrm{I}}{\mathrm{R}}
$$

where $\mathrm{V}=$ Value, $\mathrm{I}=$ Net Operating Income and $\mathrm{R}=$ Value at Risk.

As such, the important factors affecting investment output are net operating income and risk, and the level of risk that will affect value generation. In the investment process, it is necessary to evaluate the value generated on the one hand, and the risks that affect overall development on the other, as well as investors' level of risk tolerance.

In our model of the value of urban green infrastructure $\left(\mathrm{V}^{\prime}\right)$, urban planning and building design for green buildings requires an increase in construction cost (C). However, capacity incentives increase the area of land in use; increase rents, occupancy rates, and rental income; and enhance environmental quality $\left(I_{1}\right)$. Utility bills and carbon emissions are also reduced by green building design, via lower overall energy use $\left(I_{2}\right)$. The addition of new open spaces and public facilities can improve the function of the urban environment, enhance the city's ability to reduce the probability of disasters, and mitigate and relieve the impact of those disasters that do occur $\left(R_{1}\right)$. In other words, green infrastructure can both directly and indirectly affect the development value of urban land, and increase the resilience of cities to disaster risk. After green infrastructure is introduced through our urban land development value model (Equation (2), urban green infrastructure value model (source: this study)), the cost of its development and the annual value it generates 
are calculated, with an assumption that the residual value of the building will approach zero after a lifecycle of 40 years.

$$
V^{\prime}=\frac{\mathrm{I}+\left(I_{1}+I_{2}\right)}{R-R_{1}}-\frac{\mathrm{I}}{\mathrm{R}}-\mathrm{C}
$$

In that model, $V^{\prime}=$ value of urban green infrastructure; $\mathrm{I}=$ net operating income; $I_{1}=$ value of land use; $I_{2}=$ value of energy savings; $\mathrm{R}=$ risks; $R_{1}=$ value of urban disaster prevention; and $\mathrm{C}=$ urban green infrastructure development costs.

This study explores the value model of urban green infrastructure development, including the costs, values, and risks arising from the investment of green infrastructure. In addition to the land use value, energy saving and carbon reduction value, when the risk of urban disaster decreases by green infrastructure, it can increase the overall development value. After the development of green infrastructure, the value of land use, energy saving, and carbon reduction will be increased, and the risk of urban disaster will be reduced. When the urban risk is lower, the value of land use, energy saving, and carbon reduction will be higher, and vice versa. The relationship between value and risk will have a positive impact.

\section{Results and Discussion}

The aim of study is to create a quantitative value model that assists stakeholders to better understand the values of urban green infrastructure, as well as apply this model to a case of regional scale. The study implies the development of green infrastructure increases the value of land use and energy saving, and increase urban disaster prevention.

In terms of land use value, the Central District of Taichung City was the first to start construction of the 'blue belt' along the Liuchuan waterfront on 21 March 2014, and the completed site was opened to the public on 24 October 2016. This investment in green infrastructure has triggered opportunities for the further redevelopment of the Central District. As of the time of writing-December 2020-there have been 3210 real estate transactions and 292 land transactions since construction began in Liuchuan. Among them, 2516 new real estate transactions and 188 land transactions have been completed after the improvement of Liuchuan. Changes in land and real estate prices within the research area were calculated by the researchers based on data from 1 August 2012 onward, obtained from the Ministry of the Interior. This indicated that the construction of green infrastructure has coincided with an increase in the number of local land and real estate transactions, with the frequency of transactions increasing with proximity to the project area. According to the House+ website and Real Estate Transaction Price [59,60], real estate prices and the overall number of transactions in the Central District also increased significantly after the urban green infrastructure development commenced. The prices of suites, residential buildings, mansion apartments, and houses have all been rising, and although the rate of increase has recently slowed, the overall trend remains upward. This seems to confirm green infrastructure's theorized positive impact on real estate prices. In terms of the impact of green infrastructure on local development, Huang has noted that the housing stock in the Central District houses is mostly old, and homeowners would rather leave their properties idle than renovate them [61]. Fortunately, in the wake of a series of revitalization measures in the Central District by the city government, the proportion of unoccupied houses in the district has fallen from $50 \%$ to $25 \%$. Lin et al. noted that since the completion of the renovation of the Liuchuan basin, the estimated value of businesses in the area has also grown by $50 \%$ [62]. Taken together, this appears to indicate that pollution remediation and other environmental improvements to Taichung's metropolitan river has driven growth in the riverside areas' commerce and tourism, as well as achieved their fundamental environmental objectives.

In terms of the energy saving value, the domestic sewage interception facilities along both sides of the Liuchuan River, from Chongdeliu bridge to Nantunliu bridge, have completed a total of 72 sewage interception pipelines, capable of intercepting more than $57,000 \mathrm{t}$ of sewage per day. From the interception point of each trunk line, part of the sewage is 
sent to the underground gravel aeration treatment facility beneath the Zhonghua parking lot, and the resulting clean water is discharged from the outlet of the Zhongzhengliu bridge back into the Liuchuan. Another part of the sewage is introduced into the surrounding sewage pipelines and sent to the Futian Water Resources Recovery Center. These measures are coupled with low impact construction methods in the section of the river, from Zhongzheng Liu bridge to Minquanliu bridge, where the river basin itself has been altered to a green and gentle slope. The surrounding urban areas now feature permeable pavements, infiltration ditches, rain gardens, infiltration dry wells, planting ditches, and planting filter belts. Water purification is achieved through soil filtration, adsorption, and microbial decomposition, reducing non-point source pollution emissions, while retaining the original old trees, transforming the Liuchuan waterfront environment, and reducing the impact of rainfall runoff on the riverine environment.

Focusing on the urban disaster prevention value, Liuchuan's drainage is narrower on the upstream, and wider on the downstream, with the width of the upstream and downstream channels (Zhongzhengliu bridge) is differ by about 10 meters. To improve the Lichuan's flood control capacity, the channel between Zhongzhengliu bridge and Minquanliu bridge was divided into two sections, in which the embankments were widened by $8 \mathrm{~m}$, and the channel width was greatly increased from $25 \mathrm{~m}$ to $41 \mathrm{~m}$. Flood protection culvert was added below the banks of the river. In addition to the above-mentioned improvements to the water quality and flood control capacity, the river course was transformed from its traditional three-sided polished form into grass slope and multi-layer planting. Lastly, the original impervious external area was $12,300 \mathrm{~m}^{2}$, and the river banks' water permeability was barely over $0 \%$; however, the landscape as a whole has now been transformed into a permeable one.

The 'blue belt' of the Liuchuan waterfront creates a 310 meters waterfront pedestrian environment on both sides, while converting the riversides into a green and mild slope and enhances it with permeable pavement, infiltration ditches, rain gardens, infiltration dry wells, planting ditches, and planting filter strips. By the filtering, adsorption and microbial decomposition of the soil, the water purification effect is achieved, reducing non-point source pollution emissions while preserving the original old trees. About 160 trees and 3000 shrubs were added, all native to Taiwan. The water permeable area has increased by 6258 square meters, the water permeability has increased by $50 \%$, and the green area has increased by $3322 \mathrm{~m}^{2}$. The improved green cover of Liuchuan can reach to $80 \%$, and with more than 345 trees, it can reduce about $4 \mathrm{t}$ of $\mathrm{CO}_{2}$ per year. The green infrastructure under the trees can not only reduce $75 \%$ of non-point source pollution, but the vegetation can also attract and become a biological microhabitat. Lin et.al. noted that after the completion of the renovation of Liuchuan River, the business of the neighborhood businesses has increased by $50 \%$, and the price of the houses located in the vicinity of Liuchuan River has increased by $25 \%$, as shown through the real estate transaction price inquiry service of the Ministry of the Interior [62].

There are few green spaces in the Central District, and this will inevitably limit the benefits it provides. In this case, dense urban environments that are characterized by insufficient disaster preparedness increasingly confront extreme weather and natural disasters. Nevertheless, most people do not appear to fully understand the risks associated with low-quality urban space, and urban disasters will likely continue to cause significant loss of life and property. Clearly, urban land development needs to place more emphasis on reducing environmental risks.

The basic themes of existing urban green policies include promoting biodiversity $[2,8,63]$, maintaining the health of ecosystems $[10,12,64]$, adapting to climate change $[10,11,63]$, fostering a green economy [2], and improving human health and social cohesion [65]. Mell et al. showed that green infrastructure investment can result in returns to cities and metropolitan areas. The increasing number of valuable and attractive urban greening projects can be used to determine the economic value of such projects, and the resulting data should influence future decision making [66]. As previous researchers have revealed, green infrastructure elements 
benefit communities economically, socially, and environmentally (e.g., SNAP) [7]. Changes to buildings are among the most cost-effective means of reducing carbon dioxide emissions. Therefore, urban renewal provides a good intervention point for switching to sustainable fuel sources, particularly as energy infrastructure becomes cheaper as the number of buildings involved increases [67]. Shahata and Zayed developed a risk-based decision-making method to help integrate the maintenance/renewal of roads, water supply infrastructure, and sewer assets [68]. Similarly, the Malta Planning Authority found that effective urban development served particularly to restore and upgrade existing structures and infrastructure [69]. Vandermeulena et al. proposed that models can be used as a basis for fully motivated analysis, persuade key stakeholders, and increase public willingness to accept the inclusion of green infrastructure or other natural resources in land use plans [70]. Modeling can also help decision makers to coordinate community growth, environmental protection, and quality of life [20].

Thus, introducing green building design principles; planning the linkage of openspace systems; encouraging the creation and use of green public transportation systems; creating a comfortable, accessible and friendly human-centered environment; enhancing transportation convenience; and improving the quality and aesthetics of the environment by linking pedestrian and bicycle systems to roads, parks, green spaces, squares, trails, and adjacent open spaces can be expected to considerably reduce energy use, while at the same time increasing the buildings' value.

\section{Conclusion}

This research has attempted to create an integrated model of the values of several aspects of urban green infrastructure, i.e., land use value, energy saving value, and disaster prevention value, as a guide to future public and private sector investment in such infrastructure.

This research shows that using urban green infrastructure as the cornerstone of urban planning can create a comfortable and friendly urban environment. Enhancing land use value will attract commercial investment and increase commercial activities. People will also be willing to pay more to purchase or rent residential real estate. Green buildings and a more human-oriented urban environment will reduce energy use and carbon emissions, mitigate the negative impacts of extreme weather and natural disasters, facilitate adaptation to a changing climate, and reduce the probability of certain types of disasters occurring.

The proposed model can potentially be applied not only to urban development, but also to the simulation of urban green networks, which are expected to enhance urban disaster prevention functions for the reasons cited above; this, too, can aid the governments' decision making. Another advantage of this model is that it can improve urban green infrastructure pricing, in terms of land use value, energy saving value and disaster prevention value, thus making a considerable contribution to urban sustainable development.

This implies that governments should rethink the construction of urban public infrastructure in ways that will better meet the basic needs of urban life. This involves an overall urban environment in which people can relax, which includes green spaces, pedestrian spaces, squares, and green park roads. At the same time, such measures can help maintain habitats and biodiversity, reduce the risks associated with natural disasters, help cities adapt to climate change, and increase local business opportunities and inward investment.

However, the shortcomings in this model that need to be overcome in future research are that it assumes that increasing land use value and energy saving value will increase overall value, and that reducing disaster risk can increase disaster prevention value. That is, the purpose of this model's hypothesis is to strengthen the incentives for urban green infrastructure construction. In fact, this model fails to accurately describe the interactive relationships among land use value, energy saving value, and disaster prevention value. Research on such interactions, using real case data, will be one of the directions for a future revision of this model. 
Author Contributions: Conceptualization, K.-W.H. and J.-C.C.; data curation, J.-C.C.; writingoriginal draft, J.-C.C.; writing-review and editing, J.-C.C.; supervision, K.-W.H. Both authors have read and agreed to the published version of the manuscript.

Funding: This research received no external funding.

Institutional Review Board Statement: Not applicable.

Informed Consent Statement: Not applicable.

Conflicts of Interest: The authors declare no conflict of interest.

\section{References}

1. United Nations (UN). Habitat for a Better Urban Future.World Cities Report 2016: Urbanization and Development-Emerging Futures. 2016. Available online: https:/ / unhabitat.org/books/world-cities-report/ (accessed on 20 December 2020).

2. Benedict, M.A.; McMahon, E.T. Green Infrastructure: Linking Landscapes and Communities; Island Press: Washington, DC, USA, 2006.

3. Brown, P.R. The Role of Citizen Activists in Urban Infrastructure Development. In Growing Greener Cities: Urban Sustainability in the Twenty-First Century; Eugenie, L., Wachter, S.M., Eds.; University of Pennsylvania Press: Philadelphia, PA, USA, 2008; pp. 152-169.

4. UK Government. Green Infrastructure Planning Practice Guidance; UK Government: London, UK, 2016. Available online: http://planningguidance.communities.gov.uk/blog/guidance/natural-environment/green-infrastructure/ (accessed on 20 December 2020).

5. Matthews, T.; Lo, A.Y.; Byrne, J.A. Reconceptualizing green infrastructure for climate change adaptation: Barriers to adoption and drivers for uptake by spatial planners. Landsc. Urban Plan. 2015, 138, 155-163. [CrossRef]

6. Gill, S.E.; Handley, J.F.; Ennos, A.R.; Pauleit, S. Adapting cities for climate change: The role of green infrastructure. Built Environ. 2007, 33, 115-133. [CrossRef]

7. Sustainable Neighbourhood Action Program. Available online: https://trca.ca/conservation/sustainable-neighbourhoods/ urban-renewal-co-benefits / (accessed on 20 December 2020).

8. Ahern, J. Green Infrastructure for Cities: The Spatial Dimension. In Cities for the Future towards Integrated Sustainable Water and Landscape Management; Novotny, V., Brown, P., Eds.; IWA Publishing: London, UK, 2007; pp. 265-283.

9. Mell, I.C. Can green infrastructure promote urban sustainability? Proceedings of the Institution of Civil Engineers. Eng. Sustain. 2009, 1, 23-34. [CrossRef]

10. Pauleit, S.; Liu, L.; Ahern, J.; Kazmierczak, A. Multifunctional Green Infrastructure Planning to Promote Ecological Services in the City. In Urban Ecology. Patterns, Processes, and Applications; Niemelä, J., Ed.; Oxford University Press: Oxford, UK, 2011; pp. 272-286.

11. Davies, C.; Lafortezza, R. Urban green infrastructure in Europe: Is greenspace planning and policy compliant? Land Use Policy 2017, 69, 93-101. [CrossRef]

12. European Commission. A Resource-Efficient Europe-Flagship Initiative under the Europe 2020 Strategy. In Proceedings of the Communication from the Commission to the European Parliament, the Council, the European Economic and Social Committee and the Committee of the Regions, COM 21 final, Brussels, Belgium, 26 January 2011.

13. Norton, B.A.; Coutts, A.M.; Livesley, S.J.; Harris, R.J.; Hunter, A.M.; Nicholas, S.G.; Williams, N.S.G. Planning for cooler cities: A framework to prioritise green infrastructure to mitigate high temperatures in urban landscapes. Landsc. Urban Plan. 2015, 134, 127-138. [CrossRef]

14. Young, R.; Zanders, J.; Lieberknecht, K.; Fassman-Beck, E. A comprehensive typology for mainstreaming urban green infrastructure. J. Hydrol. 2014, 519, 2571-2583. [CrossRef]

15. ECOTEC Research and Consulting for NENW. The Economic Benefits of Green Infrastructure: Developing Key Tests for Evaluating the Benefits of Green Infrastructure; Natural Economy Northwest: Birmingham, UK, 2008.

16. Brody, S.D.; Highfield, W.E. Open space protection and flood mitigation: A national study. Land Use Policy 2013, 32, 89-95. [CrossRef]

17. Meerow, S.; Newell, J.P. Spatial planning for multifunctional green infrastructure: Growing resilience in Detroit. Landsc. Urban Plan. 2017, 159, 62-75. [CrossRef]

18. Tzoulas, K.; Korpela, K.; Venn, S.; Yli-Pelkonen, V.; Kaźmierczak, A.; Niemela, J.; James, P. Promoting ecosystem and human health in urban areas using GreenInfrastructure: A literature review. Landsc. Urban Plan. 2007, 81, 167-178. [CrossRef]

19. Demuzere, M.; Orru, K.; Heidrich, O.; Olazabal, E.; Geneletti, D.; Orru, H.; Faehnle, M. Mitigating and adapting to climate change: Multi-functional and multi-scale assessment of green urban infrastructure. J. Environ. Manag. 2014, 146, 107-115. [CrossRef]

20. Broussard, S.R.; Washington-Ottombre, C.; Miller, B.K. Attitudes toward policies to protect open space: A comparative study of government planning officials and the general public. Landsc. Urban Plan. 2008, 86, 14-24. [CrossRef]

21. Nazir, N.N.M.; Othman, N.; Nawawi, A.H. Role of Green Infrastructure in Determining House Value in Labuan Using Hedonic Pricing Model. Procedia Soc. Behav. Sci. 2015, 170, 484-493. [CrossRef]

22. Groot, R.d. Function-analysis and valuation as a tool to assess land use conflicts in planning for sustainable, multi-functional landscapes. Landsc. Urban Plan. 2006, 75, 175-186. [CrossRef] 
23. Council of Tree and Landscape Appraisers. Guide for Plant Appraisal, 8th ed.; International Society of Arboriculture: Champaign, IL, USA, 1992.

24. Council of Tree and Landscape Appraisers. Summary of Tree Valuation Based on CTLA Approach; International Society of Arboriculture: Champaign, IL, USA, 2003.

25. Cabe Space. The Value of Public Space; Commission for Architecture and the Built Environment: London, UK, 2004. Available online: https: / / webarchive.nationalarchives.gov.uk/20110118110609/http://www.cabe.org.uk/files/does-money-grow-ontrees.pdf (accessed on 20 December 2020).

26. Cabe Space. Does Money Grow on Trees? Commission for Architecture and the Built Environment: London, UK, 2005. Available online: http:/ / www.cabe.org.uk/publications/does-money-grow-on-trees (accessed on 20 December 2020).

27. Garrod, G.D.; Willis, K.G. Valuing goods' characteristics: An application of the hedonic price method to environmental attributes. J. Environ. Manag. 1992, 34, 59-76. [CrossRef]

28. Garrod, G.D. Social and Environmental Benefits of Forestry Phase 2: Landscape Benefits; Report to the Forestry Commission; Centre for Research in Environmental Appraisal and Management, University of Newcastle upon Tyne: Newcastle, UK, 2002.

29. Venn, S.J.; Niemela, J.K. Ecology in a multidisciplinary study of urban green space: The URGE project. Boreal Environ. Res. 2004, 9, 479-489.

30. Li, P.; Wang, Z.H. Environmental co-benefits of urban greening for mitigating heat and carbon emissions. J. Environ. Manag. 2021, 293, 112963. [CrossRef]

31. Arnold, J.; Kleemann, J.; Fürst, C. A Differentiated Spatial Assessment of Urban Ecosystem Services Based on Land Use Data in Halle, Germany. Land 2018, 7, 101. [CrossRef]

32. Breuste, J.; Artmann, M. Multi-Functional Urban Green Spaces; Springer: Cham, Switzerland, 2020; pp. $399-401$.

33. Su, Y.S. The Strategy to Mitigate the UHI Intensity for an Eco-City by Using Natural Water Areas in the Hot Humid Zone: A Case of the Tamshui River in Taipei City. Master's Thesis, Department of Architecture, China University of Technology, Taipei, Taiwan, 2012.

34. Kuo, P.Y. A Study on the Micro-Climate of Urban Parks in Tainan. Master's Thesis, Department of Architecture, National Cheng Kung University, Tainan, Taiwan, 2000.

35. Chang, C.R.; Li, M.H.; Chang, C. A preliminary study on the local cool-island intensity of Taipei city parks. Landsc. Urban Plan. 2007, 80, 386-395. [CrossRef]

36. Yu, C.; Hien, W.N. Thermal benefits of city parks. Energy Build. 2006, 38, 105-120. [CrossRef]

37. Jones, R.N.; Young, C.K.; Symons, J. Assessing the Economic Value of Green Infrastructure; Green Paper; Victoria Institute of Strategic Economic Studies, Victoria University: Melbourne, VIC, Australia, 2015; p. 67.

38. Symons, J.; Jones, R.N.; Young, C.K.; Rasmussen, B. Assessing the Economic Value of Green Infrastructure Literature Review; Victoria Institute of Strategic Economic Studies, Victoria University: Melbourne, VIC, Australia, 2015; p. 52.

39. Brink, T.P.; Badura, T.; Bassi, S.; Daly, E.; Dickie, I.H.D.S.G.; Gerdes, H.M.K.; Lago, M.; Lang, S.; Markandya, A.; Nunes, P.A.L.D.; et al. Estimating the Overall Economic Value of the Benefits Provided by the Natura 2000 Network; Final Report to the European Commission, DG Environment on Contract ENV.B.2/SER/2008/0038; Institute for European Environmental Policy, GHK, Ecologic: Brussels, Belgium, 2011; p. 222.

40. HM Government. The UK Low Carbon Transition Plan; National Strategy for Climate and Energy. 2009. Available online: http:/ / www.decc.gov.uk/en/content/cms/publications/lc_trans_plan/lc_trans_plan.aspx (accessed on 20 December 2020).

41. Yang, W.Y.; Wang, Z.Y.; Pei, H.; Zhang, J.; Krebs, P. Impact of green infrastructure on the mitigation of road-deposited sediment induced stormwater pollution. Sci. Total. Environ. 2021, 770, 145294. [CrossRef]

42. Li, L.Y.; Uyttenhove, P.; Eetvelde, V.V. Planning green infrastructure to mitigate urban surface water flooding risk-A methodology to identify priority areas applied in the city of Ghent. Landsc. Urban Plan. 2020, 194, 103703. [CrossRef]

43. Omitaomu, O.A.; Kotikot, S.M.; Parish, E.S. Planning green infrastructure placement based on projected precipitation data. J. Environ. Manag. 2021, 279, 111718. [CrossRef]

44. Yıldız, S.; Kıvrak, S.; Gültekin, A.B.; Arslan, G. Built environment design—social sustainability relation in urban renewal. Sustain. Cities Soc. 2020, 60, 102173. [CrossRef]

45. Li, C.L.; Liu, M.; Hu, Y.; Zhou, R.; Wu, W.; Huang, N. Evaluating the runoff storage supply-demand structure of green infrastructure for urban flood management. J. Clean. Prod. 2021, 280, 124420. [CrossRef]

46. Natural Economy Northwest (NENW). The Economic Value of Green Infrastructure. 2008. Available online: http://www naturaleconomynorthwest.co.uk/resources+reports.php (accessed on 20 December 2020).

47. Lin, T.P. The Research on the Performance of Raining Storage in Building Site. Master's Thesis, Department of Architecture, National Cheng Kung University, Tainan Taiwan, 1998.

48. Mentens, J.; Raes, D.; Hermy, M. Green roofs as a tool for solving the rainwater runoff problem in the urbanized 21st century? Landsc. Urban Plan. 2006, 77, 217-226. [CrossRef]

49. Duffy, A.; Jefferies, C.; Waddell, G.; Shanks, G.; Blackwood, D.; Watkins, A. A cost comparison of traditional drainage and SUDS in Scotland. Water Sci. Technol. 2008, 57, 1451-1459. [CrossRef]

50. Seters, T.V.; Rocha, L.; Smith, D.; Macmillan, G. Evaluation of green roofs for runoff retention, runoff quality, and leachability. Water Qual. Res. J. Can. 2009, 44, 33-47. [CrossRef]

51. Nisbet, T.R.; Orr, H.; Broadmeadow, S. A guide to Using Woodland for Sediment Control; Forest Research: Farnham, UK, 2004. 
52. Kousky, C.; Olmstead, S.M.; Walls, M.A.; Macauley, M. Strategically Placing Green Infrastructure: Cost-Effective Land Conservation in the Floodplain. Environ. Sci. Technol. 2013, 47, 3563-3570. [CrossRef] [PubMed]

53. Lin, C.Y.; Chung, C.P.; Lin, C.R. A Study of Vegetation Coverage and Water Storage Capacity at Taichung Metropolitan Park before and after development. J. Soil Water Conserv. 2009, 41, 31-44.

54. Hsu, K.W.; Chao, J.C. Economic Valuation of Green Infrastructure Investments in Urban Renewal: The Case of the Station District in Taichung, Taiwan. Environments 2020, 7, 56. [CrossRef]

55. Turner, R.K.; Pearce, D.; Bateman, I. Environmental Economics: An Elementary Introduction; Harvester Wheatsheaf: London, UK, 1994.

56. Jorion, P. Value at Risk: The New Benchmark for Controlling Derivatives Risk; McGraw-Hill: New York, NY, USA, 1996.

57. Water Edge Symposium 2016: Waterfront Landscape Projects in Taichung Luchuan Canal, Liuchuan Canal. Available online: https: / rdnet.taichung.gov.tw/media/518946/003.pdf (accessed on 1 July 2021).

58. Ye, S.; Tiong, R.L.K. NPV-at-risk method in infrastructure project investment evaluation. J. Constr. Eng. Manag. 2000, 126, 227-233. [CrossRef]

59. House+ Website. Available online: https://www.houseplus.tw/ (accessed on 20 December 2020).

60. Real Estate Transaction Price inquiry by the Ministry of the Interior. Available online: https://lvr.land.moi.gov.tw/login.action (accessed on 20 December 2020).

61. Huang, C.M. The Old City is Reborn, Green Willows Lined Up, Taichung Architecture Cloud, Taichung Architects Association. 2018. Available online: http:/ / www.tccarch.org.tw / cloud_detail.aspx?id=28 (accessed on 20 December 2020).

62. Lin, J.R.; Cheng, C.K.; Liao, C.Y.; Lian, J.R. Taichung City Metropolitan River (Liuchuan) Pollution Remediation and Environmental Improvement Demonstration Project, Water Resources Bureau of Taichung City Government, Electronic Newsletter of the Environmental Engineering Society of the Republic of China. 2017. Available online: https://www.cienve.org.tw/epaper/106_2/ construct1.aspx (accessed on 20 December 2020).

63. Kambites, C.; Owen, S. Renewed prospects for green infrastructure planning in the UK. Plan. Pract. Res. 2006, 21, 483-496. [CrossRef]

64. Hansen, R.; Pauleit, S. From multifunctionality to multiple ecosystem services? A conceptual framework for multifunctionality in green infrastructure planning for urban areas. AMBIO A J. Environ. Soc. 2014, 43, 516-529. [CrossRef]

65. Davies, C.; Hansen, R.; Rall, E.; Pauleit, S.; Lafortezza, R.; DeBellis, Y.; Santos, A.; Tosics, I. Green Infrastructure Planning and Implementation (GREEN SURGE). Report 5.1. The Status of European Green Space Planning and Implementation Based on an Analysis of Selected European City-Regions. 2015, pp. 1-134. Available online: http://greensurge.eu/working-packages/wp5 / files/D_5.1_Davies_et_al_2015_Green_Infrastructure_Planning_and_Implementation_v2.pdf (accessed on 20 December 2020).

66. Mell, I.C.; Henneberry, J.; Hehl-Lange, S.; Keskin, B. Promoting ecosystem and human health in urban areas using Green Infrastructure: A literature review. Urban For. Urban Green. 2013, 45, 296-306. [CrossRef]

67. Sunikka, M. Energy efficiency and low-carbon technologies in urban renewal. J. Build. Res. Inf. 2006, 34, 521-533. [CrossRef]

68. Shahata, K.; Zayed, T. Integrated Risk-Assessment Framework for Municipal Infrastructure. J. Constr. Eng. Manag. 2016, 142, 1-13. [CrossRef]

69. Malta Planning Authority. The Malta Council for Science and Technology; State of the Environment Report for Malta; Environment Protection Department: Paola, Malta, 1998.

70. Vandermeulena, V.; Verspecht, A.; Vermeire, B.; Huylenbroeck, G.V.; Gellynck, X. The use of economic valuation to create public support for green infrastructure investments in urban areas. Landsc. Urban Plan. 2011, 103, 198-206. [CrossRef] 